\title{
Process and Control Management of Ever Increasing Generation of E-Waste
}

\author{
Mihir Vaidya \\ Third Year B. Tech. Mechanical Engineering \\ Symbiosis Institute of Technology
}

\begin{abstract}
Electronic and Electrical wastes specifically know as E-waste is growing at a very high rate throughout the world but especially in developing countries like India. It is predicted that India is likely to generate about 52 million tons of Ewaste in 2020 which will be about $40 \%$ of the entire E-waste generated in the world at that time. The following article denotes the importance of this humongous growth, its effects on the environment and on us, the humans. The importance of various industrial methods and method of regulating the ewaste at a local governing level especially in India has also been suggested.
\end{abstract}

\section{Keywords}

PPPs, FDI, CRT, LCD

\section{INTRODUCTION}

Waste generation is one of the most difficult problem faced by us in the $21^{\text {st }}$ century. The amount of waste generated, its recycling and disposal are some of the major issues faced by both developed as well as developing countries. E-waste stands for Electronic waste, the waste generated from electronics and it's various components due to the advent of technological development. It is predicted that the worldwide E-waste generation will be about 65 million tons by 2017 . According to a UN report published in 2014, India is the $5^{\text {th }}$ biggest producer of E-waste generating 1.4 million tons of Ewaste. Electronic waste (e-waste) now contribute about five percent of all municipal solid waste worldwide, nearly the same amount as all plastic packaging, but it is much more hazardous. Not only developed countries generate e-waste but most developing countries in Asia generates an estimated 12 million tons each year[9].

In 2005, more than 2 million tons of e-Waste was generated in the US alone (US EPA), but only 17 to 18 percent of that was collected for recycling. The rest, more than 80 percent, was disposed of, largely in local landfills [12]. The implications of ever increasing E-waste and its random disposal into developing nations by developed countries are discussed further into this paper. This paper will highlight the various problems created by increasing E-waste in India, the various government schemes and initiatives to solve it and its importance as a business commodity to like- minded people.

\section{MAGNITUDE OF PROBLEMS CREATED BY E-WASTE IN INDIA}

It is predicted according to a report presented by Rajya Sabha that there will be a $500 \%$ rise in Television created E-waste by 2020. Amounts of harmful or non-usable components generated in Computers, Mobile Phones and Mass manufactured electronic devices lead to a further increase in Cadmium, lead and other harmful waste causing harm to both nature and us.The major problems in India are lack of legal and Environmental acceptable recycling units or plants and unclear laws and regulations on the production and recycling of E-waste in India. Most of the E-waste generated in India is obtained in metropolitan cities like Mumbai, Bangalore, and Delhi. Out of the total E-waste generated about $70 \%$ of the Ewaste is being produced by about 10 states and $60 \%$ by 65 cities according to a Report published by Rajya Sabha in 2009[1].

It is estimated that around $95 \%$ of E-waste is being recycled through an informal sector which may or may not abide by the various government regulations in place[2].

According to report published in United Nations, out of the 3 containers leaving European, at least one container consists of illegal E-waste.(3). Although it is legal to export discarded goods to poor countries if they can be reused or refurbished, much is being sent to Africa or Asia under false pretences, says Interpol. Waste collection, transportation, processing and recycling is dominated by the informal sector. Most of the Ewaste collected by various sources is dumped outside cities, towns which is then incinerated leading to an increase in pollution levels and smog. The sector is well networked and is unregulated. There are various issues regarding leakage of various toxins, poisonous substances into the environment affecting worker's safety as well as their health. It is of extreme importance that the informal and formal sector work together following various safety regulations ,clinical and efficient management of waste so that minimum damage is caused to various sectors of society from developed countries[11].

Reasons For the export of E-waste into India are -

1) Cheap labor : Rates are approximately US - \$30/ computer, India - \$2/,Computer Recycle Saving $\$ 28$ / computer

2) Weak environmental laws

3) Excess dumping of CRT tubes due to the ramp walk of flat screen monitors

4) Driven by the potential for corporate profits

\section{HARMFUL AND HAZARDOUS EFFECTS OF E-WASTE}

The following table allows us to observe the various harmful effects caused by elements present in components of e-waste.

Table 1: Harmful effects of E-waste Related Components [4][7]

\begin{tabular}{|c|c|c|}
\hline Elements & $\begin{array}{c}\text { Components } \\
\text { consisting the } \\
\text { Element }\end{array}$ & Harmful effects \\
\hline Lead & $\begin{array}{c}\text { Bulbs, Television, } \\
\text { Computer Monitors, }\end{array}$ & $\begin{array}{l}\text { Impaired } \\
\text { cognitive } \\
\text { function, }\end{array}$ \\
\hline
\end{tabular}




\begin{tabular}{|c|c|c|}
\hline & Control Boards & $\begin{array}{c}\text { behavioral } \\
\text { disturbances, } \\
\text { attention deficits, } \\
\text { affects nervous } \\
\text { system of } \\
\text { children }\end{array}$ \\
\hline Cadmium & $\begin{array}{l}\text { Batteries, Computer } \\
\text { and Monitors, } \\
\text { Resistance Boards, } \\
\text { PCBs }\end{array}$ & $\begin{array}{c}\text { Severe damage to } \\
\text { lungs, also causes } \\
\text { kidney related } \\
\text { diseases }\end{array}$ \\
\hline Mercury & $\begin{array}{l}\text { Obtained in } \\
\text { Thermostats, Flat } \\
\text { screen monitors, } \\
\text { Fluorescent tubes }\end{array}$ & $\begin{array}{l}\text { Reduces growth } \\
\text { and development } \\
\text {,reduces fertility } \\
\text { and can cause } \\
\text { muscle weakness }\end{array}$ \\
\hline Sulphur & $\begin{array}{c}\text { Found in Lead Acid } \\
\text { Batteries }\end{array}$ & $\begin{array}{c}\text { Kidney and Heart } \\
\text { Damage, Causes } \\
\text { eye irritation }\end{array}$ \\
\hline Beryllium Oxides & $\begin{array}{c}\text { Used in Heat Sinks } \\
\text { for CPU and Power } \\
\text { Transistors }\end{array}$ & $\begin{array}{l}\text { Constant } \\
\text { Exposure may } \\
\text { lead to cause } \\
\text { Lung cancer }\end{array}$ \\
\hline $\begin{array}{l}\text { Polychlorinated } \\
\text { Bi-Phenyls }\end{array}$ & $\begin{array}{l}\text { Motors ,Coolants, } \\
\text { Capacitors }\end{array}$ & $\begin{array}{c}\text { Thyroid } \\
\text { Dysfunction }\end{array}$ \\
\hline Copper & Wires, PCBs & $\begin{array}{l}\text { Headaches, Eye } \\
\text { Irritation, Throat } \\
\text { Infections }\end{array}$ \\
\hline Americium & $\begin{array}{l}\text { Radioactive Source } \\
\text { in Smoke Alarm }\end{array}$ & $\begin{array}{c}\text { It is a } \\
\text { Carcinogenic }\end{array}$ \\
\hline
\end{tabular}

The inappropriate disposal of E-waste without undergoing proper processes leads to saturation of various metals as well as non-metals such as lead, cadmium, nickel and others near urban dumping grounds. The abundance of these elements leads to a serious harm and causes illness among the local flora and fauna which includes us, the human beings[11].

\section{E-WASTE MANAGEMENT PROCESSES}

Basel Convention, is an international treaty that was designed to reduce the movements of hazardous wastes between nations, and specifically to prevent transfer of hazardous waste from developed to lesser developed countries to reduce the ever increasing danger from industrial and E-wastes types of waste generation Many Asian counties including Taiwan, Japan and South Korea have agreed to reduce the waste generation by demanding the various manufacturers to recycle $75 \%$ of their annual production.

Modifications at the productions processes, recovery and reuse of products:

Certain changes can be made in production processes which can make a change in amount of E-waste generated[5].

1) Use of materials which are biodegradable instead of use of plastic and another materials in production of chips, micro-controllers etc.

2) Use of processes which will reduce the amount of waste generated during production such as stamping, powder metallurgy in the place of simple cutting and wastage of raw material.
3) Pre-planning of raw materials like lead, mercury so that lower amount of waste is created which reduces the damage to environment.

4) Chemicals which may include acids, caustics, cyanides etc are often a hazardous waste and must be properly managed. By reducing the number of parts that have to be manufactured, the quantity of waste obtained during the process can be significantly controlled.

5) In many cases, there are Smartphone or mobile recycling boxes placed outside the companies' offices or galleries where the consumers are allowed to throw their old, used phones for certain incentives. Such methods are highly useful as these phones are recycled, undergo various processes such as electrolytic recovery, condensation or osmosis where the base metal such as Copper, Gold is retrieved reducing the waste generation.

6) The following are some methods used for Reclamation of valuable components from the waste generated [6].

Table 2: Reclamation of Valuable Components

\begin{tabular}{|c|c|}
\hline Components and Parts & Reclamation methods \\
\hline Chips & $\begin{array}{c}\text { Reclaimed during de- } \\
\text { soldering process. } \\
\text { Operational chips can be sold } \\
\text { for re-use, or precious metals, } \\
\text { including gold, silver and } \\
\text { palladium, can be extracted } \\
\text { from the chips. }\end{array}$ \\
\hline Solder & $\begin{array}{c}\text { Reclaimed during de- } \\
\text { soldering process. }\end{array}$ \\
\hline Gold & $\begin{array}{c}\text { Reclaimed during gold } \\
\text { leaching process and melted } \\
\text { into gold bars or nuggets. }\end{array}$ \\
\hline Bare Fiberglass Boards & $\begin{array}{c}\text { Remain at the end of the } \\
\text { process. Can either be sold } \\
\text { and smelted to reclaim } \\
\text { copper; or chopped and used } \\
\text { as filler in various } \\
\text { applications. }\end{array}$ \\
& \\
\hline
\end{tabular}

Motivated by the environmental effects caused by the generated e-waste, many technological changes have been effectuated[6]. The following are some of the examples:

- The replacement of CRT screens with LCD screens $(\mathrm{Pb}$ elimination but $\mathrm{Hg}$ introduction)

- The introduction of optical fibers (Cu elimination from the cablings, but $\mathrm{F}, \mathrm{Pb}, \mathrm{Y}$ and Zirconium introduction)

- The introduction of rechargeable batteries (Nickel, Cadmium reduction, but $\mathrm{Li}$ increase), etc.

5. WASTE-MANAGEMENT MODEL AT A LOCAL LEVEL IN INDIA

5.1 Many new government campaigns such as Swachh Bharat Abhiyan have been initiated by the Government of India to reduce the amount of waste disposal and proper management of E-waste, industrial waste and local type of wastages created at a local level of governance. 
5.2 Various Government Bodies, NGO's should educate people in the methods of recycling of waste, waste bifurcation and reduction methods.

5.3 Local collection points in districts or Talukas can be created where the waste can be collected by recycling organizations and bodies. People (the citizens of that district or region) can be given certain incentives or monetary advantages depending upon the type of E-waste management ideas and services they provide.

5.4 The informal collectors or workers may collect these wastes by differentiating it into various types and then supply it to formal government appointed workers.

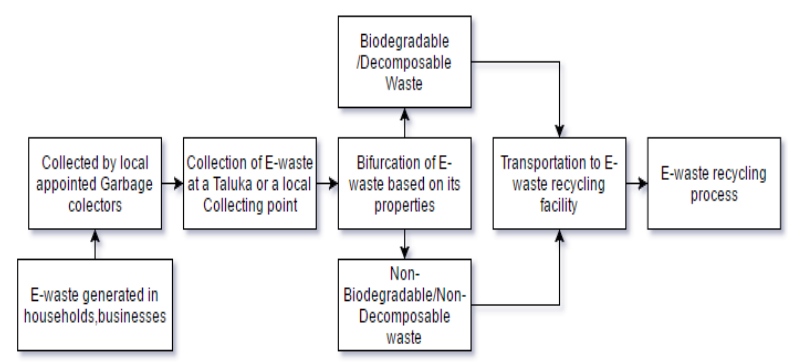

Fig 1: E-waste collection layout at a local governing level in India

A proper batch of skilled workers can be created to bifurcate and recycle the wastes depending on the process to be used, the materials and its usability which may lead to a higher employment and a planned and safe e-waste reduction.

To make a sound e-waste management process, a new working culture with new approaches suiting to the specified locality must be devised. It is a new field of profession and once people obtain exposure in its working and its advantages then it would certainly be a profit making and environment friendly local-scale occupation in the future [8].

\section{CONCLUSION}

The ESI (Environmental Sustainable Index) rank of India was 101 in 2005 and 66th in Environmental governance, which need further improvement by creating e-waste treatment infrastructure by PPPs( People, Private Partnership model in the country via Foreign Direct Investment(FDI) due to better technologies which western countries like United states, France, Germany have, which can be partnered with the cheap labor and manpower available in India which can collectively make the better e-waste treatment and techniques viable and economical. The recent government initiatives like Swachh Bharat Abhiyan and regulation to control E-waste and industrial waste generation must regulate the the ever increasing rise of disposal and dangers of E-waste materials and harmful substances. The citizens of India and the government both have a responsibility to control and properly manage the problem of E-waste in India.

\section{REFERENCES}

[1] Mahesh C. Vats, Santosh K. Singh, Status of E-Waste in India - A Review, IJIRSET, Volume 3, Issue 10,ISSN: 2319-8753, pp. 16918-16930, 2014

[2] Source-Lakshmi Raghupathy, E-Waste Recycling In India - Bridging The Gap Between The Informal And Formal Sector

[3] Source-John Vidal, “Toxic 'e-waste' Dumped in Poor Nations, 2013

[4] Shubham Gupta, Gaurav Modi ,Rahul Saini, Vijaya Agarwala, "A Review On Various Electronic Waste Recycling Techniques And Hazards Due To Its Improper Handling”, ,IRJES, pp.5-17

[5] Jennifer Namias, "The Future Of Electronic Waste Recycling In The United States: Obstacles and Domestic Solutions"

[6] G. Gaidajis , K.Angelakoglou and D. Aktsoglou E-waste: Environmental Problems and Current Management,Journal of Engineering Science and Technology Review,pp.193-199

[7] Electronic Waste - A Literature Review, Swati A. Patil, Neetu M. Sharma,IJSR,pp.1622-1624

[8] Anil Kumar Saini and Abhishek Taneja, Managing EWaste in India-Review, IJAER,2012

[9] Ram Krishna, Ms.SampaSaha Study Paper On e-waste management,pp.1-23

[10] Shagun,AshwaniKush,Anupam Arora ,"Proposed Solution of e-Waste Management, International Journal of Future Computer and Communication", Vol. 2, No. 5, October 2013

[11] Molly Macauley, Karen Palmer, JhihShyang Shih,.Dealing with Electronics Waste: modeling the costs and environmental benefit of computer monitor disposal. Journal of Environmental Management. pp.68,2003

[12] M. Khurrum S. Bhutta, Adnan Omar and Xiaozhe Yang, Electronic Waste: A Growing Concern in Today's Environment, Economics Research International,Volume 2011 